\title{
Ewing sarcoma of the left big toe with trans-articular skip lesion A case report
}

\author{
Ahmad F Kamal, ${ }^{1}$ Muhammad Nagieb, ${ }^{1}$ Errol U. Hutagalung, ${ }^{1}$ Bambang Budiatmoko, ${ }^{2}$ Saukani Gumay, ${ }^{3}$ \\ Abdul Muthalib ${ }^{4}$ \\ 1 Orthopaedic and Traumatology Division, Faculty of Medicine, University of Indonesia/Dr. Cipto Mangunkusumo Hospital, Jakarta, \\ Indonesia \\ 2 Department of Radiology, Faculty of Medicine, University of Indonesia/Dr. Cipto Mangunkusumo Hospital, Jakarta, Indonesia \\ 3 Department of Pathology Anatomy, Faculty of Medicine, University of Indonesia, Jakarta, Indonesia \\ 4 Department of Haemato-Oncology, Faculty of Medicine, University of Indonesia/Dr. Cipto Mangunkusumo Hospital, Jakarta, \\ Indonesia
}

\begin{abstract}
Abstrak
Kami laporkan satu kasus sarcoma Ewing pada ibu jari kaki kiri dengan trans-artikular skip-lesion pada diafisis tulang tibia kiri. Dalam periode 1995-2004 di rumah Sakit Ciptomangunkusumo, telah didiagnosis 20 kasus sarcoma Ewing, namun hanya terdapat satu kasus dengan skip-lesion. Diagnosis transarikular skip lesion pada sarcoma Ewing dikonfirmasi dalam forum clinicopathological conferrence. Riwayat penyakit, pemeriksaan fisik yang cermat dan pemeriksaan laboratorium darah serta foto ronsen toraks dan tulang yang terlibat disertakan dalam evaluasi rutin pasien dengan tumor tulang. Payaran tulang seluruh tubuh dengan menggunakan Tc 99 diperlukan untuk menentukan staging. Pada pasien ini, telah dilakukan amputasi ibu jari kaki kiri dan biopsy terbuka diafisis tibia untuk mengkonfirmasi diagnosis. Setelah itu, pasien menjalani kemoterapi induksi dan kemudian dilakukan amputasi diatas lutut. Pasien meninggal dunia 10 bulan setelah diagnosis ditegakkan akibat metastasis jauh. (Med J Indones 2008; 18: 139-44)
\end{abstract}

\begin{abstract}
We report the case of the patient who had Ewing Sarcoma in whom radiological and hystopathological appearances revealed a tumor mass in the left big toe along with trans-artikular skip lesion on the left diaphysis of tibia. In Cipto Mangunkusomo Hospital since 1995 until 2004 we have found 20 Ewing sarcoma cases, but only one skip lesion Ewing sarcoma was found. The diagnosis of transarticular skip lesion in association of Ewing sarcoma was confirmed in clinicopathological conferrence. The initial evaluation of all patients included the recording of the medical history, physical examination, and hematological studies. Radiographs of the chest and the site of the primary tumor were made routinely. Systemic staging was performed with use of total-body bone scan. Ray amputation of left big toe and open biopsy from mass of mid-shaft of tibia had been done to confirm the diagnosis. The patient underwent induction chemotherapy and above knee amputation. Ten months after diagnosis, he died because of advanced-distant metastasis. (Med J Indones 2008; 18: 139-44)
\end{abstract}

Key words: Ewing sarcoma, trans-articular skip lesion

Ewing sarcoma is a highly malignant primary neoplasm of bone that often metastasizes to other sites, including other bones, by the time the patient is first seen by a physician. The frequency in the United States depends on the patient's age. Tumor occurrence ranges from 0.3 case per $1,000,000$ children younger than 3 years to as high as 4.6 cases per 1,000,000 adolescents aged 15-19 years. Internationally the annual incidence rate averages less than 2 cases per $1,000,000$ children. ${ }^{3}$ In Cipto Mangunkusomo Hospital since 1995 until 2004 we have found 20 (20 of 118 malignancy in bone in children) Ewing sarcoma cases. But we only found one skip lesion case of Ewing sarcoma.
We report a rare case of Ewing sarcoma of the left big toe in association with transarticular skip lesion on the left diaphysis of tibia and proximal femur.

\section{CASE PRESENTATION}

A sixteen-year old man presented with the lump on his left big toe growing since three months before admission. The lump at that site accompanied by ulceration starting to appear one month ago. It began when he clipped his toe nails. He was brought immediately to a general hospital and had a Rosser 
plasty. However, it worsen after surgery characterized by getting bigger and more painful. Foul smell came out from it. By then, he was brought to Pasar Rebo Hospital. Plain X-Ray was performed and he was suggested for amputation by orthopedic surgeon. But the family refused, and therefore the doctor referred him to Ciptomangunkusumo Hospital.

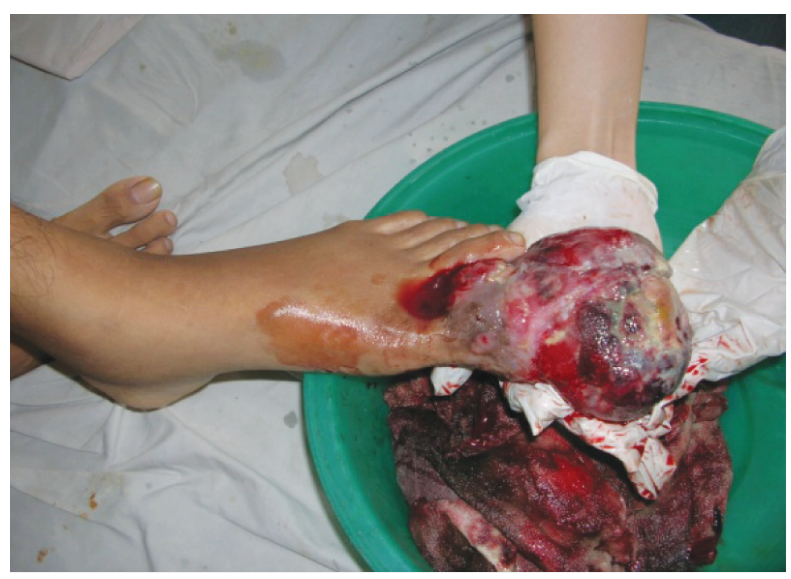

Figure 1. Tumor at the left big toe with ulceration and nectic tissue

It was found that in addition to the lump on the toe, he also had another growing lump which was located on his left leg. This lump occurred at the same time as the lump on his toe, but smaller in size.

We found on his toe ulcerated mass, pus, and necrotic tissue. The mass was $11 \times 10 \times 8 \mathrm{~cm}$ in size, and $30 \mathrm{~cm}$ circumferential in length with soft consistence, well defined margin (Fig.1), actively bleed, and tender.

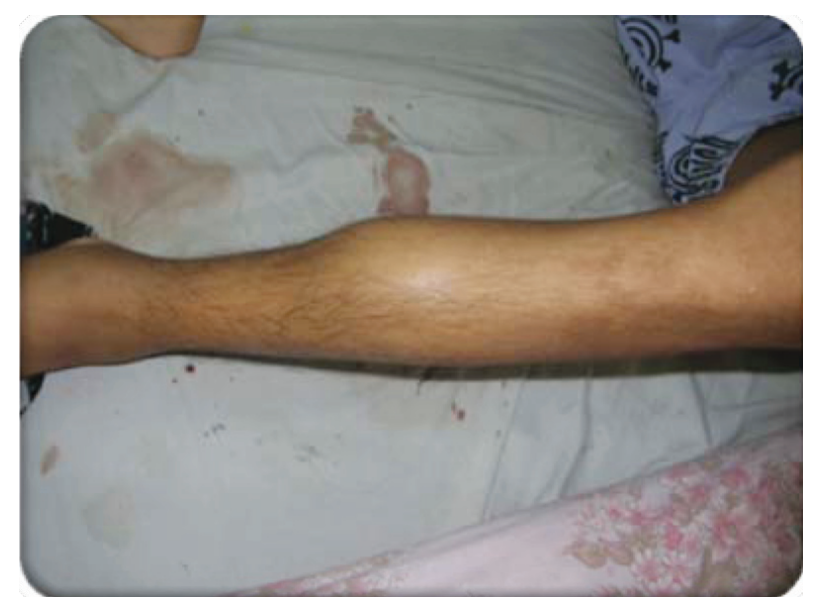

Figure 2. Skip lesion mass at left leg
In the mid part of left leg, there was painless mass, 8 $\mathrm{cm}$ in diameter, no vein dilatation, no ulceration, firm in consistence, and ill defined margin (Fig.2).

\section{Laboratory findings}

The laboratory findings showed ESR $75 \mathrm{~mm} / \mathrm{h}(0,0$ $10,0 \mathrm{~mm} / \mathrm{h}$ ), serum alkaline phosphatase $297 \mu / \mathrm{dl}$ (35187), CRP $36,8 \mu / \mathrm{dl}(0,0-05,0)$ and lactic dehydrogenase $234 \mu / \mathrm{dl}(100-190)$.

\section{Imaging findings}

Left foot AP and lateral Plain X rays showed destruction of the distal phalanx of left big toe and soft tissue mass. (Fig.3)

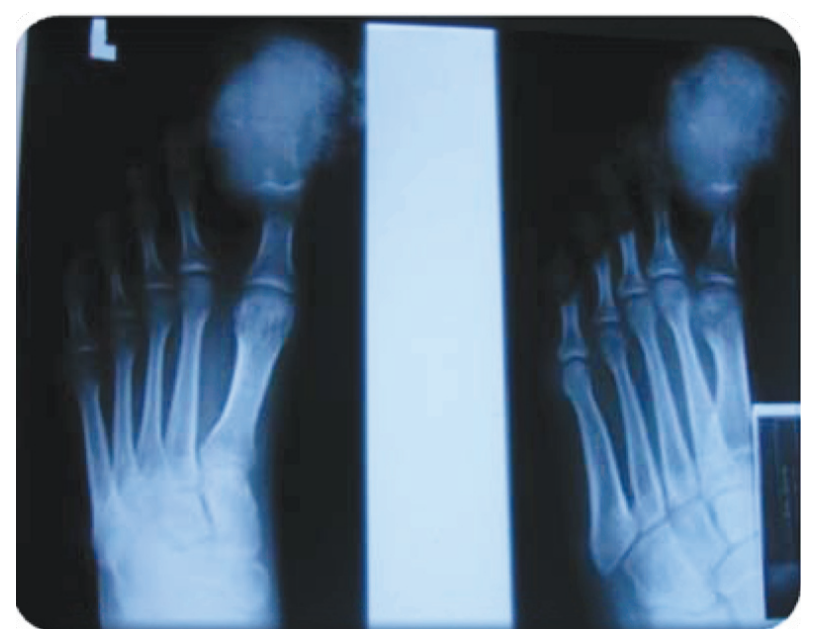

Figure 3. Left foot AP and lateral X rays : destruction of left big toe with soft tissue mass.

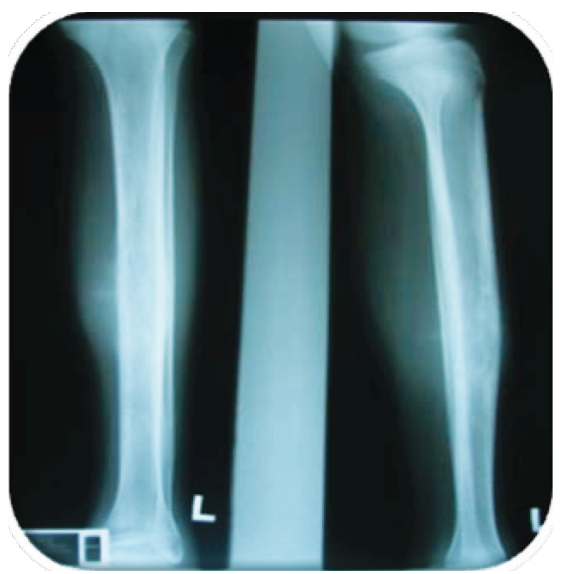

Figure 4. Left leg Ap and lateral X rays : destruction medulla shaft of the tibia with permeative pattern, with periosteal reaction 
On the left leg plain X rays AP and lateral views showed permeative lytic destruction of shaft of the tibia and also periosteal reaction. (Fig.4)

Bone scintigraphy showed increased activity in the left foot, mid-shaft of the tibia, proximal tibia and proximal femur (Fig.5).

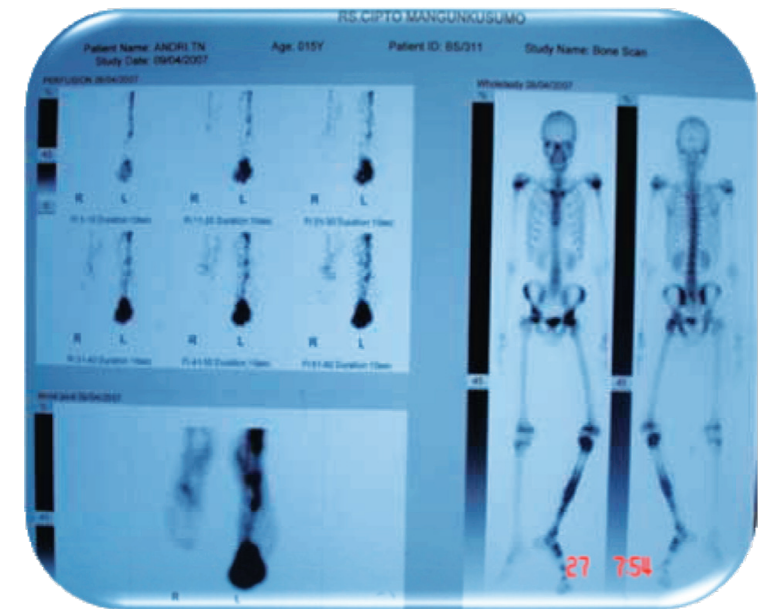

Figure 5. Bone scintigraphy showed increased uptake in the left foot, mid-shaft of the tibia, proximal tibia and proximal femur.

The patient was admitted to the hospital and underwent a fine needle biopsy and also discussed in the Clinico Pathological Conference (CPC).

Fine Needle Aspiration Biopsy (FNAB) specimen was obtained from the mass at foot. The result was small round cells sarcoma, preferred PNET/Ewing sarcoma (Fig.6). In CPC, patient was diagnosed as Ewing sarcoma of the left big toe with suspicious trans-articular skip lesion on the left mid-diaphysis of tibia. We also concluded that increased activity in proximal tibia and also proximal femur as inflammatory process.

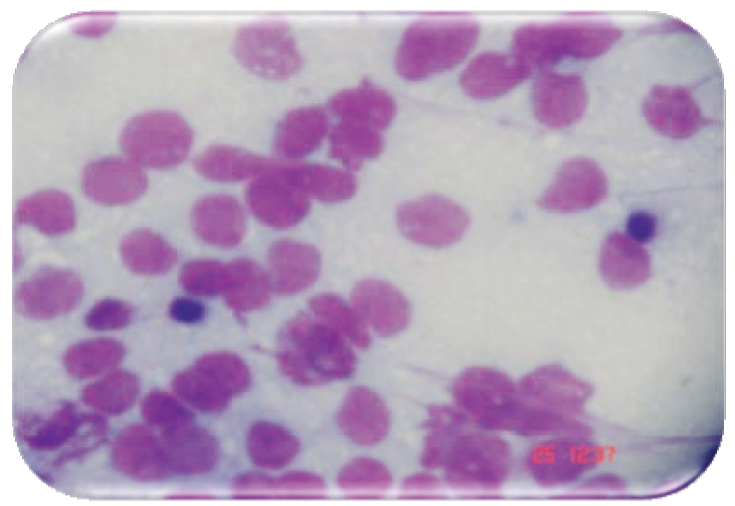

Figure 6. FNAB from left big toe showed small round cells as Ewing sarcoma/PNET.
We decided to do ray amputation for left big toe and open biopsy of mass on the left mid-diaphysis of tibia to confirm diagnosis.

Macroscopically, speciment from ray amputation showed tan-grey mass, haemorrhagic and necrotic tissue and also pus. (Fig.7a-b).

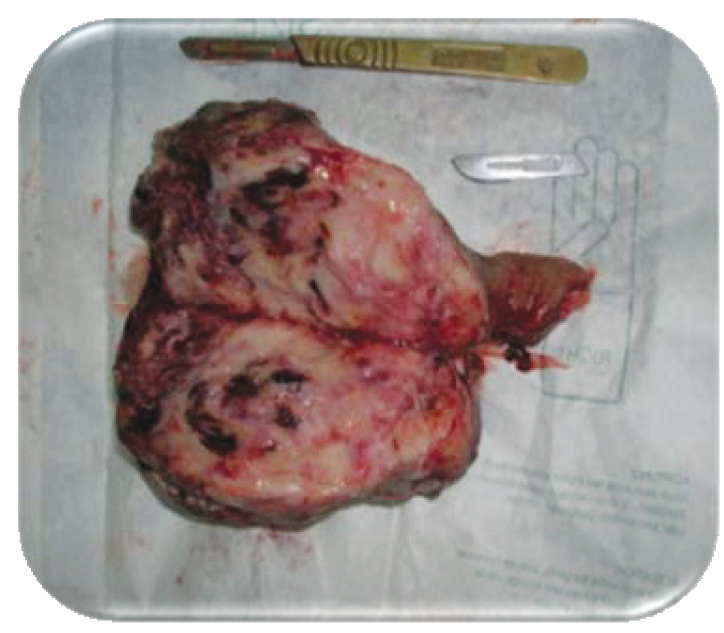

Figure 7a. Speciment from ray amputation showed tan-grey mass, haemorrhagic and necrotic tissue.

Grossly, open biopsy specimen of left mid diaphysis mass showed tumor mass with yellowish white appeareance and semi fluid tissue.

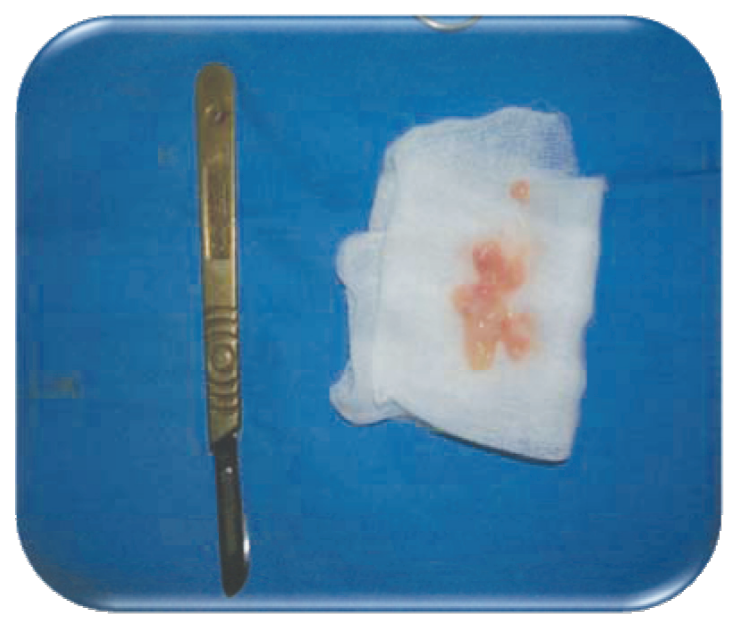

Figure 7b. Open biopsy speciment showed yellowish white mass and semi fluid tissue.

Histopathological findings of both specimens showed small round cells with round nuclei containing fine cromatin with eosinophilic cytoplasms (Fig.8a-c). 


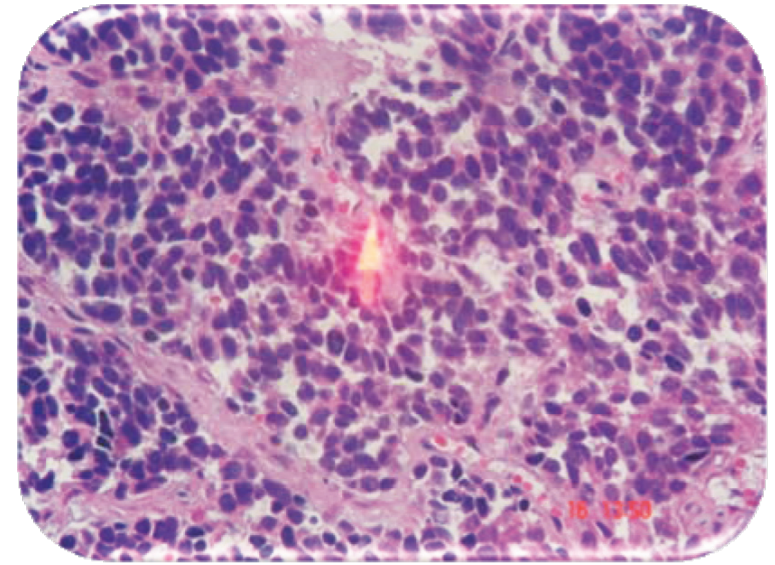

Figure $8 a$

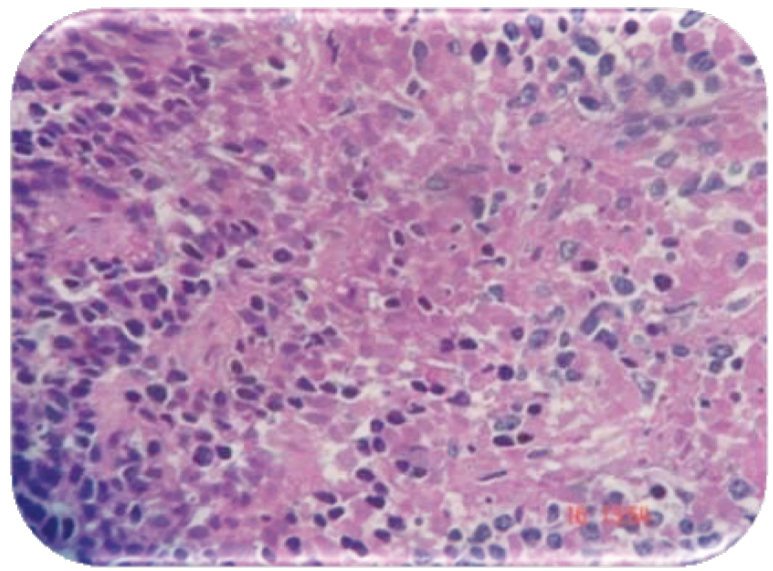

Figure $8 b$. That the tumour cells are larger have prominent nuclei and irregular contours. Hommer Wright Rosettes were found.

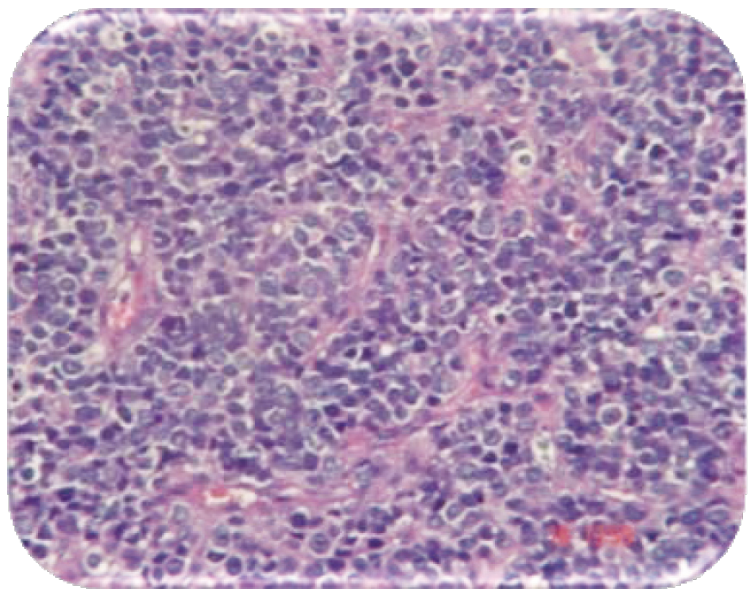

Figure 8c. Fig. 8a-b. speciments from left big toe, 8a) showed small round cell with the eosinophilic cytoplasm; b) showed Hommer Wright Rosettes; Fig.8c) showed small round cell with eosinopilic cytoplasm (speciment from left leg).
Induction chemotherapy consisted of vincristine, actinomycin D, ifosfamide, and adriamycin (VAIA) 7 cycles was administered.

After four cycles induction chemotherapy, the tumor mass at the leg enlarged and lymphnodes enlargement in the inguinal region were found, thus confirming inefficiency of the chemotherapy (Fig.9).

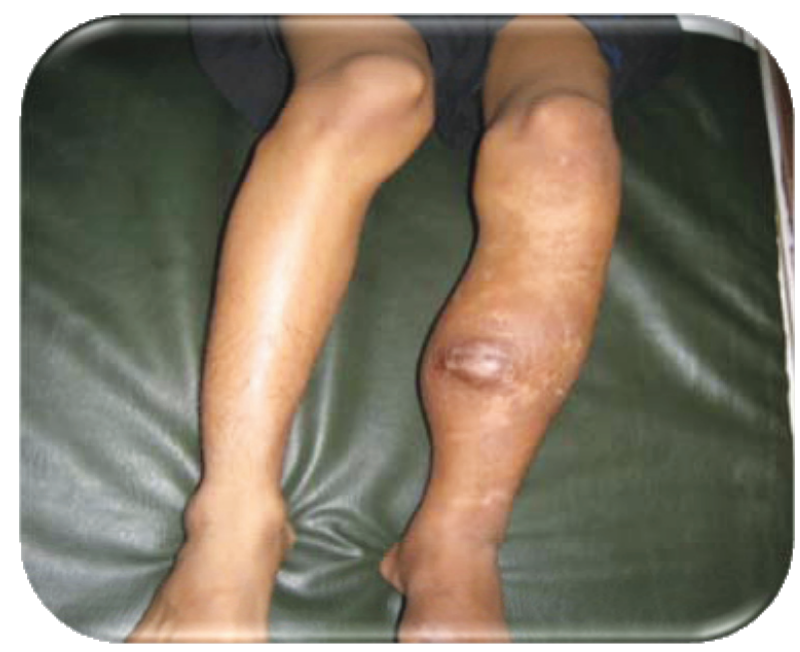

Figure 9. Showed clinical picture after 4 cyles chemotherapy

Therefore, the patient was scheduled for limb ablation surgery-above knee amputation and incisional biopsy of lymphnodes in the inguinal region followed by three cycles adjuvant chemotherapy. Nine months after diagnosis, distance metastases were detected at the craniofascial region and humerus. And one month later, the pasient was dead due to cerebral metastasis.

\section{DISCUSSION}

Ewing's sarcoma is a highly malignant tumor that is a type of peripheral primitive neuroectodermal tumor (PNET). Ewing's sarcoma is found in the lower extremity more than in the upper extremity, but any long tubular bone may be affected. The most common sites are the metaphysis and diaphysis of the femur followed by the tibia and humerus. ${ }^{1,2}$ The tumor is derived from red bone marrow. Most frequently, it is observed in children and adolescents aged 4-15 years and rarely develops in adults older than 30 years. Ewing sarcoma accounts for approximately $5 \%$ of biopsyanalyzed bone tumors and approximately one third of primary bone tumors. It is the second most common 
malignant bone tumor in young patients. ${ }^{3,4}$ Males are affected more frequently than females, with a ratio of approximately $1.5: 1{ }^{4}$

Ewing Sarcoma on the left big toe is a very rare case. Never is transarticular skip lesion in association with Ewing sarcoma reported before in our institution, and perhaps in Indonesia. In 1989, Sundaram et al reported a case of skip lession Ewing sarcoma at the femur. ${ }^{4,5}$

The term skip lesion has been used to describe a separate focus of osteosarcoma that developed synchronously in the same bone as another osteosarcoma, in the absence of direct anatomical extension between the lesions or of metastases. ${ }^{1,4}$ Others have verified the development of skip osteosarcomas, although there has been disagreement about their frequency.

In our patient, the transarticular skip lesion of Ewing sarcoma may have been missed at the first CPC. The lesion in the proximal tibia and proximal femur where considered as inflammatory process because of very rare case. But both radiography and bone scintigraphy examination indicated that the midshaft of tibia lesion was a skip lesion. These were supported by histopathological results that confirmed were Ewing sarcoma.

The European Intergroup Cooperative Ewing's Sarcoma Study (EICESS) included 369 patients treated with local therapy and chemotherapy based on 14 courses of vincristine, actinomycin D, cyclophosphamide or ifosfamide, and Adriamycin with or without etoposide. The 3-year event-free survival rate was $66 \%$ in patients with localized tumors, $43 \%$ in those with lung metastases at initial diagnosis, and $29 \%$ in those with other metastases. ${ }^{1}$

The inclusion of resection in the protocol for the treatment of Ewing sarcoma provides an opportunity to examine the effect of preoperative chemotherapy on the primary tumor. In patients who have osteosarcoma, a tumor that usually is treated with preoperative chemotherapy, chemotherapy-induced tumor necrosis facilitates operative resection and the extent of the necrosis is a major prognostic indicator of both local and systemic recurrence. ${ }^{6}$ Jürgens et al. as well as Picci et al. suggested that the histological response to preoperative chemotherapy may also be an important indicator of the systemic outcome for patients who have Ewing sarcoma. Verril et al mentioned that a large tumor volume was negative prognostic factors. ${ }^{5,7}$
Approximately 19 per cent of patients who have Ewing sarcoma have metastatic disease when they are first seen, which indicates a very poor prognosis. ${ }^{5}$

Wunder JS et al. have found that chemotherapy-induced tumor necrosis is also the most important indicator of event-free survival for patients who have had operative treatment of Ewing sarcoma. ${ }^{6}$

A lesser extent of tumor necrosis following chemotherapy was associated with an increased risk of systemic recurrence.

Similar findings have been reported in association with osteosarcoma. ${ }^{7}$ Whereas some tumors respond rapidly, less responsive tumors, which are associated with a poor outcome, require an increased amount of chemotherapy to achieve an adequate clinical response before resection. Indeed, the clinical response to initial chemotherapy has been associated with the outcome in patients who have Ewing sarcoma, although it has been less predictive than the histological response. ${ }^{7}$

Ewing Sarcoma on the left big toe with transarticular skip lesion is extremly rare case. The diagnosis of transarticular skip lesion in association of Ewing sarcoma was confirmed in clinicopathological conference. The patient who has Ewing sarcoma has metastatic disease when he is first seen, which indicates a very poor prognosis.

\section{REFERENCES}

1. Frassica FJ, Frassica DA, Pritchard DJ, Schomberg PJ, Wold LE, Sim FH. Ewing sarcoma of the pelvis. Clinicopathological features and treatment. J Bone Joint Surg Am. 1993; 75: 1457-65.

2. San-Julian M, Aquerreta JD, Benito A: Indications for epiphyseal preservation in metaphyseal malignant bone tumors of children: relationship between image methods and histological findings. J Pediatr Orthop. 1999; 19(4): 543-8.

3. Fletcher CDM, Unni KK, Mertens F. Pathology and Genetics of Tumors of Soft Tissue and Bone. In: Kleihues P, Sobin LH, editors. World Health Organization: Classification of Tumors. Lyon: IARC Press; 2002: p 298-300.

4. Unni KK, Inward CY, Bridge JA, Kindblom LG, Wld LE. Small cell Malignancies Ewing Sarcoma. In :AFIP Atlas of Tumors Pathology Tumor of Bones and Joint. Washington DC; 2005: p 209-22.

5. Verrill MW, Judson IR, Harmer CL: Ewing's sarcoma and primitive neuroectodermal tumor in adults: are they different from Ewing's sarcoma and primitive neuroectodermal tumor in children? J Clin Oncol. 1997; 15(7): 2611-21. 
6. Wunder JS,Paulian G,Huvos AG,Heller G,Meyer PA, Healey JH. The Histological Response to Chemotherapy as a Predictor of the Oncological Outcome of Operative Treatment of Ewing Sarcoma. J Bone Joint Surg Am. 1998; 80-A(7): 1020-33.
7. Sundaram M, Merenda G, McGuire MM. A skip lesion in association with Ewing sarcoma. Report of a case. J Bone Joint Surg Am. 1989;71: 764-8. 